\title{
Influence of Environment on the Content and Composition of Microbial Free Amino Acid Pools
}

\author{
By D. W. TEMPEST AND J. L. MEERS* \\ Microbiological Research Establishment, Porton, near Salisbury, Wiltshire \\ AND C. M. BROWN \\ Department of Microbiology, Medical School, University of Newcastle upon Tyne
}

(Accepted for publication 8 October 1970)

\begin{abstract}
SUMMARY
The free amino acid pool contents of Gram-negative bacteria (Aerobacter aerogenes, Erwinia carotovora, Pseudomonas fluorescens) were studied as functions of the growth environment and were compared with those from correspondingly grown cultures of Gram-positive bacteria (Bacillus subtilis var. niger, B. megaterium, B. polymyxa) and the yeast Saccharomyces cerevisiae.

Although the pools of the Gram-positive bacteria and the yeast contained five to 20 times the concentration of free amino acids present in the pools of Gram-negative bacteria, all pools were similar in containing only a limited range of detectable amino acids. Glutamate invariably predominated and generally accounted for over $50 \%$ of the total amino acid content of the pool. The contents and composition of pools from micro-organisms maintained in steady states in chemostat cultures did not vary with time, but changed significantly with changes in either growth rate or the nature of the growth limitation. However, these pool variations were small compared with those resulting from addition of $2 \%(\mathrm{w} / \mathrm{v}) \mathrm{NaCl}$ to a culture of growing bacteria. With cultures of Gram-negative bacteria, sudden changes in medium salinity effected marked and rapid changes in free glutamate content; with Grampositive bacteria, similar changes occurred, but extremely slowly. Addition of $4 \%(\mathrm{w} / \mathrm{v}) \mathrm{NaCl}$ to growing yeast cultures brought about no observed changes in pool size or composition. These results are discussed with reference to the involvement of free amino acids in synthesis and functioning of microorganisms.
\end{abstract}

\section{INTRODUCTION}

The macromolecular composition and metabolic activity of micro-organisms vary to a considerable extent with changes in their growth environment (Herbert, I96I ; Neidhardt, 1963; Brown \& Rose, I969 $a, b$; Tempest, 1970). These phenotypic changes in cell structure and functioning reflect changes in genetic expression and are presumably mediated by some environmentally linked mechanism. Thus, changes in the growth condition must affect primarily the intracellular concentrations of substances reacting directly with the genetic control mechanisms; those most likely to act in this capacity within a microbial cell being the low molecular weight 'pool' constituents. Therefore in attempting to analyse the relationship between environment and microbial

\footnotetext{
* Present address: Novo Industri A/S, Fuglebakkevej 115, 2200 Copenhagen N, Denmark.
} 
physiology it is logical to examine quantitatively the effects of specific environmental changes on the composition of microbial pools.

One of the most obvious conclusions to be drawn from a survey of the literature on microbial pools - particularly amino acid pools - is that they are extremely variable and markedly dependent on the nutritional complexity of the growth medium (Holden, 1962). Thus, in order to rationalize observed changes in the content and composition of such pools in organisms grown in different environments, as many variables as possible must be closely controlled. To fulfil this requirement we have used a chemostat and have limited our investigations to organisms growing in a series of simple salts media in which the sole sources of nitrogen and carbon were $\mathrm{NH}_{3}$ and glucose, respectively. Thus we have avoided complications associated with the transport and accumulation of exogenously-supplied amino acids (see Britten \& McClure, I962).

Previous studies, using a chemostat to provide both specifically defined and closely regulated environments (see Tempest, 1969, 1970), revealed that the parameters most extensively affecting microbial physiology were (i) the chemical nature of the environment, particularly the nature of the growth-limiting component of the medium, (ii) the growth rate, and (iii) the medium osmolarity (e.g. $\mathrm{NaCl}$ concentration). Consequently we have systematically examined the effects of each of these parameters on the amino acid pools of different organisms growing in environments that were, in all other respects, rigidly controlled. A preliminary account of some of the results obtained has been published previously (Tempest, Meers \& Brown, 1970).

\section{METHODS}

Organisms. Aerobacter aerogenes (NCTC 4I8), Pseudomonas fluorescens (KB I), Erwinia carotovora, Bacillus subtilis var. niger, B. megaterium (KM) and B. polymyxa. Each was maintained by monthly subculture on Tryptic meat-digest, agar slopes. Saccharomyces cerevisiae (described by Brown \& Hough, 1965) was subcultured monthly on yeast extract $(\mathrm{I} \%, \mathrm{w} / \mathrm{v})$, peptone $(2 \%, \mathrm{w} / \mathrm{v})$, glucose $(2 \%, \mathrm{w} / \mathrm{v})$, agar.

Growth conditions. The organisms were grown in 0.51 . Porton-type chemostats, with automatic pH control (Herbert, Phipps \& Tempest, I965). Media used for the growth of bacteria were as follows. Glucose-limited: $\mathrm{Na}_{2} \mathrm{HPO}_{4}, \mathrm{I} \cdot 0 \mathrm{~mm} ; \mathrm{NH}_{4} \mathrm{H}_{2} \mathrm{PO}_{4}$, Io mM; $\left(\mathrm{NH}_{4}\right)_{2} \mathrm{SO}_{4}, 6 \mathrm{mM} ; \mathrm{K}_{2} \mathrm{SO}_{4}, 2 \mathrm{mM}$; citric acid, I mM; $\mathrm{MgCl}_{2} 0.6 \mathrm{mM} ; \mathrm{CaCl}_{2}$ and $\mathrm{FeCl}_{3}$, each O.I mM; $\mathrm{MnCl}_{2}$ and $\mathrm{ZnCl}_{2}$, each $2.5 \times \mathrm{IO}^{-5} \mathrm{M} ; \mathrm{CuCl}_{2}, \mathrm{CoCl}_{2}$ and $\mathrm{Na}_{2} \mathrm{MoO}_{4}$, each $5 \times \mathrm{IO}^{-6} \mathrm{M}$; glucose, $14 \mathrm{mM}$. $\mathrm{NH}_{3}$-limited: $\left(\mathrm{NH}_{4}\right)_{2} \mathrm{SO}_{4}, 5 \mathrm{~mm} ; \mathrm{NaH}_{2} \mathrm{PO}_{4}, 20 \mathrm{~mm}$; $\mathrm{K}_{2} \mathrm{SO}_{4}, 2 \mathrm{mM}$; citric acid, I mM; $\mathrm{MgCl}_{2}, 0.6 \mathrm{mM} ; \mathrm{CaCl}_{2}, \mathrm{FeCl}_{3}, \mathrm{MnCl}_{2}, \mathrm{ZnCl}_{2}, \mathrm{CuCl}_{2}$, $\mathrm{CoCl}_{2}$ and $\mathrm{Na}_{2} \mathrm{MoO}_{4}$, as specified above; glucose, $60 \mathrm{mM}$. $\mathrm{PO}_{4}^{3-}$-limited: $\mathrm{Na}_{2} \mathrm{HPO}_{4}$, I mM; $\mathrm{K}_{2} \mathrm{SO}_{4}, 2 \mathrm{mM} ;\left(\mathrm{NH}_{4}\right)_{2} \mathrm{SO}_{4}$, IO $\mathrm{mM}$; citric acid, I mM; $\mathrm{MgCl}_{2}, 0.6 \mathrm{~mm} ; \mathrm{CaCl}_{2}$, $\mathrm{FeCl}_{3}, \mathrm{MnCl}_{2}, \mathrm{CuCl}_{2}, \mathrm{CoCl}_{2}$ and $\mathrm{Na}_{2} \mathrm{MoO}_{4}$, as specified above; glucose, $60 \mathrm{~mm}$. Mge-limited: $\mathrm{Na}_{2} \mathrm{HPO}_{4}$, I mM; $\mathrm{NH}_{4} \mathrm{H}_{2} \mathrm{PO}_{4}$, IO mM; $\left(\mathrm{NH}_{4}\right)_{2} \mathrm{SO}_{4}, 6 \mathrm{mM} ; \mathrm{K}_{2} \mathrm{SO}_{4}$, $2 \mathrm{mM}$; citric acid, $0.5 \mathrm{mM} ; \mathrm{MgCl}_{2}, 0.2 \mathrm{mM} ; \mathrm{CaCl}_{2}, \mathrm{FeCl}_{3}, \mathrm{MnCl}_{2}, \mathrm{ZnCl}_{2}, \mathrm{CuCl}_{2}$, $\mathrm{CoCl}_{2}$ and $\mathrm{Na}_{2} \mathrm{MoO}_{4}$, as specified above; glucose, $60 \mathrm{~mm}$. $\mathrm{K}^{+}$-limited: $\mathrm{Na}_{2} \mathrm{HPO}_{4}$, I mM; $\mathrm{NH}_{4} \mathrm{H}_{2} \mathrm{PO}_{4}$, Io mM; $\left(\mathrm{NH}_{4}\right)_{2} \mathrm{SO}_{4}, 6 \mathrm{mM} ; \mathrm{K}_{2} \mathrm{SO}_{4}, 0.5 \mathrm{mM}$ (for Gram-negative bacteria) or I mM (for Gram-positive bacteria); citric acid, I $\mathrm{mM} ; \mathrm{MgCl}_{2}, 0.6 \mathrm{~mm}$; $\mathrm{CaCl}_{2}, \mathrm{FeCl}_{3}, \mathrm{MnCl}_{2}, \mathrm{ZnCl}_{2}, \mathrm{CuCl}_{2}, \mathrm{CoCl}_{2}$ and $\mathrm{Na}_{2} \mathrm{MoO}_{4}$, as specified above; glucose, $60 \mathrm{~mm}$. With all cultures, except that which was ammonia-limited, the $\mathrm{pH}$ was controlled automatically by the addition of $4 \mathrm{M}-\mathrm{NH}_{3}$, as required. 
The basal growth medium for the yeast had the following composition: $\mathrm{KH}_{2} \mathrm{PO}_{4}$, I $5 \mathrm{mM} ; \mathrm{MgSO}_{4}, 4 \mathrm{mM} ; \mathrm{CaCl}_{2}, \mathrm{I} \mathrm{mM}$; inositol, $\mathrm{I} \cdot \mathrm{I} \times \mathrm{IO}^{-4} \mathrm{M}$; pyridoxine $\mathrm{HCl}, \mathrm{I} \cdot \mathrm{O} \times$ $\mathrm{IO}^{-5} \mathrm{M}$; calcium pantothenate, $\mathrm{I} \cdot \mathrm{O} \times \mathrm{IO}^{-5} \mathrm{M}$; thiamine $\mathrm{HCl}, \mathrm{I} \cdot 2 \times \mathrm{IO}^{-6} \mathrm{M}$; biotin, $4 \times \mathrm{IO}^{-9} \mathrm{M}$; with trace amounts of $\mathrm{Zn}^{2+}, \mathrm{MoO}_{4}^{2-}, \mathrm{Ca}^{2+}, \mathrm{Fe}^{3+}$ and $\mathrm{Mn}^{2+}$. For glucose limitation, glucose (I $2 \mathrm{mM})$ and $\left(\mathrm{NH}_{4}\right)_{2} \mathrm{SO}_{4}$ ( $15 \mathrm{mM}$ ) were added, while for $\mathrm{NH}_{3}$ limitation, glucose $(60 \mathrm{~mm})$ and $\left(\mathrm{NH}_{4}\right)_{2} \mathrm{SO}_{4}(2 \mathrm{~mm})$ were added.

Analytical procedures. Bacterial concentration (mg. equiv. dry wt organisms/ml. culture) was determined by the method of Tempest, Hunter \& Sykes (I965). The free amino acid pool content and composition was assessed as follows: a volume of culture containing approximately $30 \mathrm{mg}$. equiv. dry wt organisms (in the case of Gramnegative bacteria), or $5 \mathrm{mg}$. equiv. dry wt organisms (in the case of Gram-positive bacteria), was centrifuged (3000 $\mathrm{g}, 3 \mathrm{~min}$.) and the supernatant fluid separated and discarded. The pellet of organisms was then dispersed in ice-cold $0.25 \mathrm{~N}-\mathrm{HClO}_{4}$ (final volume of $5.0 \mathrm{ml}$.) and was kept at $4^{\circ}$ for about $10 \mathrm{~min}$. before again being centrifuged $(3000 \mathrm{~g}, 5 \mathrm{~min}$.) and the supernatant fluid collected. Yeast concentration was determined by the membrane filter method of Brown \& Rose (I969a). The free amino acid pool was extracted from cells with boiling water as described by Dawson (I965). Standard volumes $(0.4 \mathrm{ml}$.) of amino acid extract were applied to the columns of a Technicon automatic amino acid analyser, along with a known amount ( $0.05 \mu$ mole) of norleucine as the internal standard and the individual amino acids were separated, assayed with ninhydrin reagent and recorded automatically. The amounts of each amino acid in the extracts were determined from the strip chart recordings by measurement of peak areas and subsequent reference to standard curves (prepared from data obtained with mixtures of purified amino acids in $0.25 \mathrm{~N}-\mathrm{HClO}_{4}$ ). With each chromatogram the individual peak areas were corrected for variations in the peak areas of the internal standard; the standard errors were then all within $\pm 10 \%$ of the mean values.

$A$ note on the extraction of bacterial pools. Since the amino acid pool must be in a highly dynamic state in growing bacteria, large changes in pool content and composition could occur during the manipulation period ( $<5 \mathrm{~min}$.) prior to the addition of $\mathrm{HClO}_{4}$. However, no differences were detected between samples that were rapidly cooled after removal from the growth vessel and processed at $4^{\circ}$ and those that were not chilled and processed at room temperature. Indeed, holding the sample at $20^{\circ}$ for 5 min. after removal from the growth vessel and before centrifuging had only a small effect on the concentration of individual free amino acids in the extracted pool. Differences in the amino acid pool content and composition of bacteria, when they occurred, were therefore truly representative of differences in the growing bacteria and not artefacts produced on processing samples.

\section{RESULTS}

As mentioned above, no difference was observed between extracts prepared from cultures that had been processed either at $4^{\circ}$ or at $20^{\circ}$; the free amino acid content and composition of the pool seemingly did not change appreciably during the short period between sampling and $\mathrm{HClO}_{4}$ extraction. Similarly, the pool amino acids extracted from three separate $\mathrm{NH}_{3}$-limited cultures of Aerobacter aerogenes, grown at a fixed rate $\left(0.3 \mathrm{~h}^{-1}\right)$, temperature $\left(35^{\circ}\right)$ and $\mathrm{pH}$ value $(6 \cdot 8)$ were markedly similar. Thus the pool concentrations of glutamic acid and alanine (the two predominant amino acids; Table I) were $5 \cdot 4,5 \cdot 3,5 \cdot 8 \mathrm{~mm}$ and $\mathrm{I} \cdot 5, \mathrm{I} \cdot 6, \mathrm{I} \cdot 4 \mathrm{mM}$, respectively. 


\section{The content and composition of bacterial amino acid pools}

Large differences in the intracellular free amino acid contents of Gram-positive and Gram-negative bacteria were found by Taylor (1947). Indeed, using specific amino acid decarboxylases to assay the intracellular free amino acids (released by heating the organisms at $100^{\circ}$ ) she concluded that the Gram-negative organisms totally lacked an amino acid pool. Although this conclusion was erroneous (see Mandelstam, I958), gross differences between the pool contents of Gram-positive and Gram-negative bacteria have frequently been observed (see Holden. 1962) and are apparent here (Table I). However, in contrast to previous data, the data shown in Table I were

Table I. Pool free amino acid contents of different bacteria grown in chemostat cultures $\left(D=0.3 h^{-1}, 35^{\circ}, p H 6.8\right)$, in simple salts media, with growth limited by the availability of $\mathrm{NH}_{3}$

Organisms were grown, and samples processed, as described in the Methods. The concentrations of each amino acid in extracts was assessed by measurement of peak areas on the traces from the automatic amino acid analyser. These concentrations were related to the intracellular free amino acid concentrations by assuming the cell-bound water content to be four times the bacterial dry weight.

\begin{tabular}{|c|c|c|c|c|c|c|}
\hline \multirow[t]{2}{*}{ 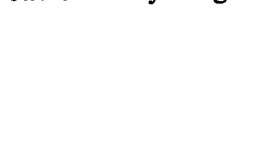 } & \multicolumn{3}{|c|}{ Gram-negative bacteria } & \multicolumn{3}{|c|}{ Gram-positive bacteria } \\
\hline & $\begin{array}{l}\text { Aerobacter } \\
\text { aerogenes }\end{array}$ & $\begin{array}{l}\text { Erwinia } \\
\text { carotovora }\end{array}$ & $\begin{array}{l}\text { Pseudomonas } \\
\text { fluorescens }\end{array}$ & $\begin{array}{l}\text { Bacillus } \\
\text { subtilis }\end{array}$ & $\begin{array}{c}B . \\
\text { megaterium }\end{array}$ & $\begin{array}{c}B . \\
\text { polymyxa }\end{array}$ \\
\hline Amino acid & \multicolumn{6}{|c|}{ (Intracellular free amino acid concentration, $\mathrm{mm}$ ) } \\
\hline Glutamate & $5 \cdot 8$ & 47 & $9 \cdot 6$ & 103 & 62 & 82 \\
\hline $\begin{array}{l}\text { Glutamine/ } \\
\text { threonine }\end{array}$ & $0 \cdot 1$ & 0.4 & $1 \cdot 4$ & $2 \cdot 6$ & 0.5 & 21 \\
\hline Proline & n.d. & n.d. & 0.7 & $\mathbf{I} \cdot \mathbf{I}$ & 0.9 & n.d. \\
\hline Aspartate & n.d. & 0.1 & $I \cdot 2$ & 0.3 & $0 \cdot 1$ & $3 \cdot 1$ \\
\hline Lysine & n.d. & 0.8 & 0.9 & $2 \cdot 0$ & $I \cdot 3$ & $16 \cdot 5$ \\
\hline Isoleucine & n.d. & 0.2 & n.d. & 0.8 & 0.3 & $3 \cdot 3$ \\
\hline Serine & n.d. & 0.2 & $I \cdot 0$ & 0.6 & 0.2 & 0.5 \\
\hline Glycine & 0.3 & 0.5 & 0.3 & $3 \cdot 4$ & $I \cdot 5$ & $7 \cdot \mathbf{I}$ \\
\hline Alanine & $I \cdot 4$ & 0.9 & 0.5 & $3 \cdot I$ & 0.6 & 20 \\
\hline Valine & 0.4 & 0.9 & 0.5 & $4 \cdot 2$ & $2 \cdot 4$ & $2 \cdot 8$ \\
\hline Leucine & n.d. & 0.2 & n.d. & 0.9 & 0.3 & n.d. \\
\hline $\begin{array}{l}\text { Total free amino } \\
\text { acid pool (mM) }\end{array}$ & 8.0 & $8 \cdot 9$ & I6.I & $122 \cdot 0$ & $70 \cdot 1$ & $156 \cdot 3$ \\
\hline $\begin{array}{l}\text { Glutamate portion } \\
\text { of pool }(\%)\end{array}$ & 72 & 53 & 59 & 84 & 89 & 52 \\
\hline
\end{tabular}

derived from cultures that were grown in media of identical composition and at rates, temperatures and $\mathrm{pH}$ values that were uniform throughout. Furthermore, since the growth of the cultures was limited by the availability of the nitrogen source $\left(\mathrm{NH}_{3}\right)$ these pools should contain the minimum concentrations of each amino acid necessary for the organisms to function (that is, grow) in the prescribed medium, at the imposed rate.

Significantly, not all the amino acids present in the proteins of bacteria were present in the pools in detectable concentrations (that is, greater than $0.1 \mathrm{mM}$ ). In particular, the pools of both Gram-positive and Gram-negative bacteria generally lacked tryptophan, tyrosine, phenylalanine, histidine, arginine, cysteine and methionine. Indeed, the 
only amino acids that were present in appreciable amounts were glutamate and alanine; valine, glutamine and lysine generally were present in lesser amounts. Invariably, glutamic acid was the predominant amino acid and accounted for between 52 and $89 \%$ of the total amino acid content in these $\mathrm{NH}_{3}$-limited bacteria (Table I).

Influence of growth rate, and the nature of the growth limitation, on the pool free amino acid content and composition of Aerobacter aerogenes

It is logical to suppose that when the growth of an organism is limited by the availability of either glucose (the sole carbon source) or $\mathrm{NH}_{3}$ (the sole nitrogen source) its pool would contain minimal levels of the various amino acids. But clearly (Table 2) the total concentrations of free amino acids present in Aerobacter aerogenes grown in media containing an excess of glucose and $\mathrm{NH}_{3}$ (for example $\mathrm{Mg}^{2+}$-limited or $\mathrm{PO}_{4}^{3-}-$ limited) were not markedly different from those in organisms that were either $\mathrm{NH}_{3}$ - or glucose-limited. However, there were obvious differences in the contents of the individual amino acids, particularly glutamate and alanine. Thus glucose- or $\mathrm{NH}_{3}$-limited A. aerogenes contained about four times as much free glutamate as free alanine; $\mathrm{Mg}^{2+}$-limited organisms had about equimolar amounts of each, and $\mathrm{PO}_{4}^{3-}$-limited organisms contained three times as much free alanine as free glutamate (Table 2). Again, it should be pointed out that the temperature, $\mathrm{pH}$ value and growth rate were uniform, and maintained constant throughout; only the relative concentrations of glucose: $\mathrm{NH}_{3}: \mathrm{Mg}^{2+}: \mathrm{PO}_{4}^{3-}$ in the simple salts medium feeding the chemostat cultures were different (see Methods).

Table 2. Influence of the nature of the growth-limiting component of the medium on the free amino acid pool content and composition of Aerobacter aerogenes growing in a chemostat culture ( $\left.D=0.3 h^{-1}, 35^{\circ}, \mathrm{pH} 6 \cdot 8\right)$

The conditions of growth and treatment of samples were as specified in Table I. Concentrations expressed as mM, assuming a cell water content four times the dry weight.

\begin{tabular}{|c|c|c|c|c|}
\hline \multirow[b]{2}{*}{ Amino acid } & \multicolumn{4}{|c|}{ Growth condition } \\
\hline & Glucose-limited & $\mathrm{NH}_{3}$-limited & $\mathrm{Mg}^{2+-}$ limited & $\mathrm{PO}_{4}^{3-}$-limited \\
\hline Glutamate & $3 \cdot 4$ & 5.8 & $3 \cdot 5$ & $\mathbf{I} \cdot \mathbf{I}$ \\
\hline Glutamate/threonine & n.d. & O.I & 0.3 & 0.2 \\
\hline Proline & n.d. & n.d. & 0.3 & $0 \cdot I$ \\
\hline Aspartate & n.d. & n.d. & 0.3 & $0 \cdot I$ \\
\hline Lysine & n.d. & n.d. & 0.2 & O.I \\
\hline Isoleucine & n.d. & n.d. & n.d. & n.d. \\
\hline Serine & n.d. & n.d. & n.d. & $0 \cdot I$ \\
\hline Glycine & 0.7 & 0.3 & 0.6 & 0.4 \\
\hline Alanine & 0.8 & $\mathrm{I} \cdot 4$ & $3 \cdot I$ & $3 \cdot 0$ \\
\hline Valine & 0.8 & 0.4 & $\mathbf{I} \cdot \mathbf{I}$ & 0.6 \\
\hline Leucine & n.d. & n.d. & n.d. & n.d. \\
\hline $\begin{array}{l}\text { Total free amino acid } \\
\text { pool (mM) }\end{array}$ & $5 \cdot 7$ & $8 \cdot 0$ & $9 \cdot 4$ & $5 \cdot 8$ \\
\hline
\end{tabular}

n.d. $=$ Not detectable (that is, less than $0.1 \mathrm{mM}$ ).

Although the effect of the growth-limiting component of the medium on the pool amino acid content of Aerobacter aerogenes was not as anticipated, the influence of growth rate (that is, culture dilution rate) on the content of free amino acids was completely predictable (Table 3 ). Increasing the dilution rate from 0.1 to 0.3 to $0.7 \mathrm{~h}^{-1}$ (which would provoke a progressive increase in the rate of protein synthesis) effected 
a progressive increase in the total concentration of intracellular free amino acids from 5.5 to 8.0 to $14.7 \mathrm{mM}$. Not all the detectable amino acids increased proportionately in concentration; the overall increase was principally due to changes in the levels of free glutamate and alanine (Tables 2, 3).

Table 3. Influence of growth rate on the free amino acid pool content and composition of Aerobacter aerogenes, growing in a chemostat $\left(35^{\circ}, \mathrm{pH} 6.8\right)$ in a simple salts medium in which growth is limited by the availability of $\mathrm{NH}_{3}$

The conditions of growth and treatment of samples were as specified in Table $\mathbf{~}$. Concentrations are expressed as $\mathrm{mM}$, assuming a cell water content four times the dry weight.

\begin{tabular}{|c|c|c|}
\hline \multirow[b]{2}{*}{ Amino acid } & \multicolumn{2}{|c|}{ Dilution rate $\left(\mathrm{h} .^{-1}\right)$} \\
\hline & 0.1 & 0.7 \\
\hline Glutamate & $4 \cdot 0$ & $9 \cdot 3$ \\
\hline Glutamine/threonine & 0.2 & 0.2 \\
\hline Proline & 0.1 & $0 \cdot I$ \\
\hline Aspartate & n.d. & 0.2 \\
\hline Lysine & 0.2 & 0.2 \\
\hline Isoleucine & n.d. & 0.1 \\
\hline Serine & 0.1 & $0 . I$ \\
\hline Glycine & 0.3 & 0.5 \\
\hline Alanine & 0.4 & $3 \cdot I$ \\
\hline Valine & 0.2 & 0.9 \\
\hline Leucine & n.d. & n.d. \\
\hline $\begin{array}{l}\text { Total free amino acids } \\
\text { (mM) }\end{array}$ & $5 \cdot 5$ & $14 \cdot 7$ \\
\hline
\end{tabular}

Influence of medium osmolarity on the content and composition of bacterial amino acid pools

Though the various media used (see Methods) differed principally in the proportions of glucose, $\mathrm{NH}_{3}, \mathrm{Mg}^{2+}$ and $\mathrm{K}^{+}$they were also not of equivalent osmolarity. Indeed, when glucose was in excess of requirement much acid was produced and much titrant was required to maintain the culture $\mathrm{pH}$ constant, so it was not possible to prescribe or control the osmolarity. Instead, we decided to study this parameter independently and chose to effect osmolarity changes by adding graded amounts of $\mathrm{NaCl}$ to the various media.

With an $\mathrm{NH}_{3}$-limited culture of Aerobacter aerogenes, increasing $\mathrm{NaCl}$ content of the medium from $<0 \cdot \mathrm{I}$ to 2 to $4 \%$ (w/v) effected a dramatic increase in the content and composition of the amino acid pool (Table 4 and, for comparison, Tables 2, 3). The effect was progressive and varied with growth rate: at a dilution rate of $0 \cdot \mathrm{I} \mathrm{h.}^{-1}$, addition of $4 \%(\mathrm{w} / \mathrm{v}) \mathrm{NaCl}$ to the medium caused a ninefold increase in the pool free amino acid content; at a dilution rate of $0.3 \mathrm{~h}^{-1}$, a similar addition of $\mathrm{NaCl}$ effected a I7-fold increase. Again, not all of the different amino acids present in the pool increased proportionately; the gross changes in pool amino acid content were due almost entirely to changes in its glutamic acid content (Table 4).

The data contained in Table 4 are steady state values derived from samples of organisms that had grown for several generation-times in the particular environment. In order to assess the nature of the mechanisms regulating pool amino acid levels (particularly pool glutamate levels) kinetic data were required. Thus changes in the 
pool content and composition of $\mathrm{Mg}^{2+}$-limited Aerobacter aerogenes (cultures of which contained an excess of $\mathrm{NH}_{3}$ and glucose) were followed immediately after addition of $\mathrm{NaCl}$ to $2 \%(w / v)$. The data obtained are plotted in Fig. I $a$. There was an immediate large increase in pool glutamate, which reached a maximum level within $20 \mathrm{~min}$. (that is, one-seventh of the culture doubling time at a dilution rate of $0.3 \mathrm{~h}^{-1}$ ); the pool glutamine also increased initially but then diminished, and all other amino acids either did not vary in concentration or increased only slowly.

Table 4. Influence of the medium $\mathrm{NaCl}$ concentration on the free amino acid pool content of $\mathrm{NH}_{3}$-limited Aerobacter aerogenes growing in a chemostat culture $\left(35^{\circ}, \mathrm{pH} 6.8\right)$ at different dilution rates

The conditions of growth and treatment of samples were as specified in Table I. Concentrations are expressed as $\mathrm{mm}$, assuming a cell water content of four times the bacterial dry weight.

\begin{tabular}{|c|c|c|c|c|c|c|}
\hline & \multicolumn{6}{|c|}{ Dilution rate $\left(h^{-1}\right)$} \\
\hline & \multicolumn{2}{|c|}{0.1} & \multicolumn{2}{|c|}{$0 \cdot 3$} & \multicolumn{2}{|r|}{0.7} \\
\hline & $\begin{array}{c}2 \% \\
\mathrm{NaCl}\end{array}$ & $\begin{array}{c}4 \% \\
\mathrm{NaCl}\end{array}$ & $\begin{array}{c}2 \% \\
\mathrm{NaCl}\end{array}$ & $\begin{array}{c}4 \% \\
\mathrm{NaCl}\end{array}$ & $\begin{array}{c}2 \% \\
\mathrm{NaCl}\end{array}$ & $\begin{array}{c}4 \% \\
\mathrm{NaCl}\end{array}$ \\
\hline Glutamate & $19 \cdot 1$ & $47 \cdot 4$ & $30 \cdot 2$ & 113.5 & $72 \cdot 9$ & No growth \\
\hline Glutamine/threonine & 0.3 & 0.6 & 0.4 & 16.9 & $4 \cdot 7$ & No growth \\
\hline Proline & 0.1 & 0.2 & $\mathrm{I} \cdot \mathrm{O}$ & $I \cdot 3$ & $2 \cdot 2$ & No growth \\
\hline Aspartate & n.d. & n.d. & n.d. & 0.5 & 0.5 & No growth \\
\hline Lysine & 0.4 & 0.3 & 0.4 & $\mathrm{I} \cdot 2$ & 0.6 & No growth \\
\hline Isoleucine & n.d. & n.d. & n.d. & n.d. & n.d. & No growth \\
\hline Serine & 0.1 & 0.1 & 0.1 & 0.3 & 0.1 & No growth \\
\hline Glycine & 0.6 & 0.6 & $I \cdot I$ & $1 \cdot 3$ & 0.8 & No growth \\
\hline Alanine & 0.4 & $I \cdot I$ & $I \cdot 5$ & $3 \cdot 0$ & $5 \cdot 2$ & No growth \\
\hline Valine & $0 \cdot 1$ & 0.1 & 0.3 & $I \cdot 4$ & $2 \cdot 7$ & No growth \\
\hline Leucine & n.d. & n.d. & n.d. & $I \cdot 2$ & n.d. & No growth \\
\hline $\begin{array}{l}\text { Total free amino } \\
\text { acids (mM) }\end{array}$ & $2 I \cdot I$ & $50 \cdot 4$ & 35.0 & $140 \cdot 6$ & $89 \cdot 7$ & No growth \\
\hline
\end{tabular}

n.d. = Not detectable (that is, less than $0.1 \mathrm{~mm}$ ).

Since the pool glutamate level changed extremely rapidly on adding $\mathrm{NaCl}$ to the environment, it was important to establish whether the change was caused by an increase in the rate of synthesis de novo of glutamate, or from turnover of intracellular constituents (presumably not protein since glutamate increased disproportionately to the other amino acids). With washed suspensions of $\mathbf{M g}^{2+}$-limited Aerobacter aerogenes suspended in $\mathrm{NaCl}$-containing media that were either complete, or lacked added $\mathrm{NH}_{3}$, the rate of glutamate accumulation greatly depended on the presence of free $\mathrm{NH}_{3}$. Thus addition of $\mathrm{NaCl}$ to the environment directly affected the rate of glutamate synthesis de novo.

Irrespective of the nature of the growth-limiting component of the medium, the pool glutamate level increased substantially upon addition of $\mathrm{NaCl}$. Thus in the presence of $2 \%(\mathrm{w} / \mathrm{v}) \mathrm{NaCl}$ the steady state pool glutamate of Aerobacter aerogenes (growing at a dilution rate of $0.3 \mathrm{~h}^{-1}, 35^{\circ}, \mathrm{pH} 6.8$ ) were: glucose-limited, $37 \mathrm{~mm}$; $\mathrm{NH}_{3}$-limited, $30 \mathrm{mM}$; $\mathrm{Mg}^{2+}$-limited, $40 \mathrm{mM}$; $\mathrm{PO}_{4}^{3-}$-limited, $54 \mathrm{mM}$ (cf. Table 2). Surprisingly, the $\mathrm{PO}_{4}^{3-}$-limited organisms (which normally had a very small glutamate pool) responded to the greatest extent to changes in the medium $\mathrm{NaCl}$ content; whereas in the absence of added $\mathrm{NaCl}$ free glutamate accounted for less than $20 \%$ of the total pool amino 
acid concentration, in the presence of $2 \%(\mathrm{w} / \mathrm{v}) \mathrm{NaCl}$ glutamate accounted for over $80 \%$.

The concentrations of free amino acids (particularly glutamate) within the pools of other Gram-negative bacteria (Erwinia carotovora, Escherichia coli, Pseudomonas fluorescens) were also markedly influenced by the $\mathrm{NaCl}$ content of the growth medium. But Gram-positive bacteria behaved differently. Thus when $\mathrm{NaCl}(2 \%, w / v)$ was added to a $\mathrm{Mg}^{2+-}$ limited culture of Bacillus subtilis var. niger (dilution rate of $0.3 \mathrm{h.} .^{-1}$,

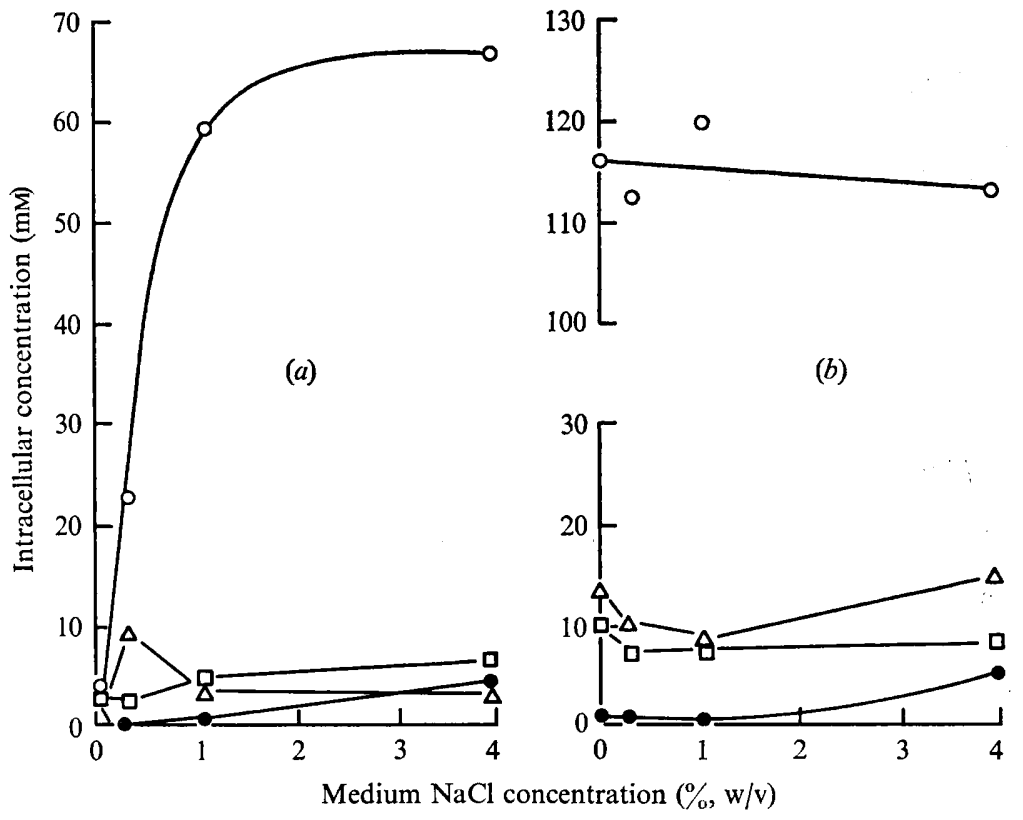

Fig. I. Changes in the pool concentrations of $(O)$ free glutamate, $(\odot)$ proline, $(\triangle)$ glutamine and $(\square)$ alanine following the addition of $\mathrm{NaCl}(2 \%, w / v$, final concentration) to steady state $\mathrm{Mg}^{2+}$-limited cultures of (a) Aerobacter aerogenes and (b) Bacillus subtilis var. niger, growing in chemostats at a dilution rate of $0.3 \mathrm{~h}^{-1}\left(35^{\circ}, \mathrm{pH} 6.8\right)$.

$\left.35^{\circ}, \mathrm{pH} 6.8\right)$ there was no immediate increase in the content of free glutamic acid, or of any other amino acid (Fig. $\mathrm{l} b$ ). After $60 \mathrm{~min}$. exposure to $2 \%(\mathrm{w} / \mathrm{v}) \mathrm{NaCl}$, in the growth medium, the pool free amino acid concentration had increased only from I60 to $163 \mathrm{~mm}$; but after a further $72 \mathrm{~h}$. growth in the presence of $2 \%(\mathrm{w} / \mathrm{v}) \mathrm{NaCl}$, the steady state total intracellular free amino acid concentration was $190 \mathrm{mM}$.

Similar results were obtained when $\mathrm{NaCl}(2 \%$ w/v) was added to glucose-limited, $\mathrm{NH}_{3}$-limited or $\mathrm{PO}_{4}^{3-}$-limited cultures of Bacillus subtilis var. niger. In every case the pool amino acid concentration was not immediately affected but ultimately increased; invariably the increase was due largely to increases in intracellular glutamate, glutamine and proline (Table 5). The effect of medium $\mathrm{NaCl}$ content on the pool proline content was progressive, and particularly marked at the higher $\mathrm{NaCl}$ concentrations (Fig. 2).

Epstein \& Schultz (1965) and Tempest \& Meers (1968) reported that addition of $\mathrm{NaCl}$ to growing cultures of Gram-negative bacteria (Escherichia coli, Aerobacter aerogenes) effected a large increase in their cellular $\mathrm{K}^{+}$content and concluded that this 


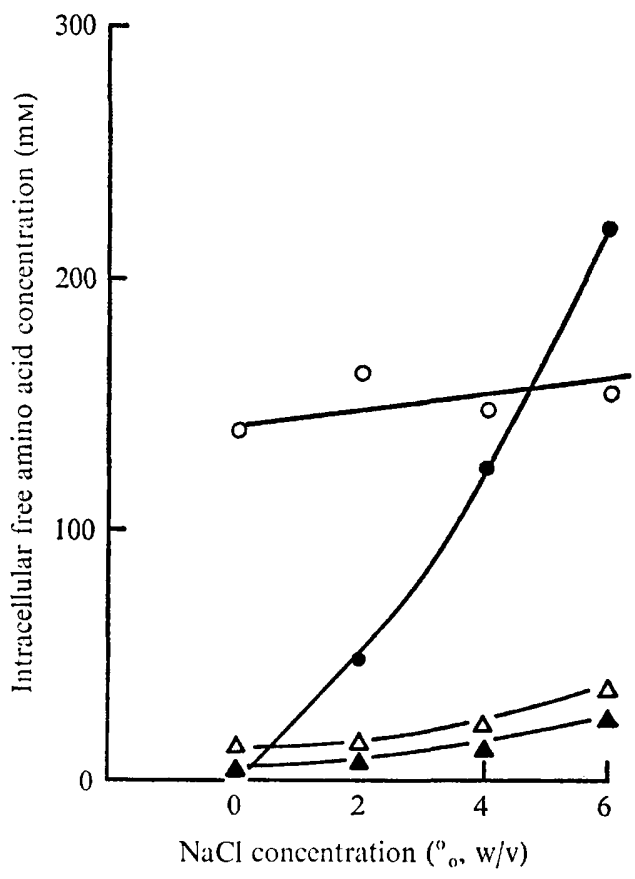

Fig. 2. Influence of medium $\mathrm{NaCl}$ concentration on the steady state pool concentrations of $(O)$ free glutamate, $(\bullet)$ proline, $(\triangle)$ glutamine and $(\Delta)$ alanine in $\mathbf{P O}_{4}^{3-}$-limited Bacillus subtilis var. niger growing in a chemostat at a dilution rate of $0.2 \mathrm{~h}^{-1}\left(35^{\circ}, \mathrm{pH} 6 \cdot 8\right)$.

Table 5. The influence of medium $\mathrm{NaCl}$ content on the steady state free amino acid pool content and composition in variously limited cultures of Bacillus subtilis var. niger, growing in simple salts media in chemostats ( $\left.D=0.3 h^{-1}, 35^{\circ}, p H 6.8\right)$

The conditions of growth and processing of samples were as described in Table I. Amino acid concentrations are expressed as $\mathrm{mm}$, assuming a cell water content equal to four times the dry weight of organisms.

Bacillus subtilis var. niger pool compositions

\begin{tabular}{|c|c|c|c|c|c|c|c|c|}
\hline \multirow[b]{2}{*}{ Amino acid } & \multicolumn{2}{|c|}{ Glucose-limited } & \multicolumn{2}{|c|}{$\mathrm{NH}_{3}$-limited } & \multicolumn{2}{|c|}{$\mathrm{Mg}^{2+}$-limited } & \multicolumn{2}{|c|}{$\mathrm{PO}_{4}^{3-}$-limited } \\
\hline & 0 & $\begin{array}{c}2 \% \\
\mathrm{NaCl}\end{array}$ & 0 & $\begin{array}{c}2 \% \\
\mathrm{NaCl}\end{array}$ & 0 & $\begin{array}{c}2 \% \\
\mathrm{NaCl}\end{array}$ & 0 & $\begin{array}{c}2 \% \\
\mathrm{NaCl}\end{array}$ \\
\hline Glutamate & 130 & 145 & 103 & II3 & 103 & 138 & I3I & 148 \\
\hline $\begin{array}{l}\text { Glutamine/ } \\
\text { threonine }\end{array}$ & $\mathbf{I} \cdot 7$ & $9 \cdot 5$ & $2 \cdot 6$ & $4 \cdot 7$ & $9 \cdot 3$ & $2 \mathrm{I} \cdot 8$ & $7 \cdot 7$ & $32 \cdot 7$ \\
\hline Proline & n.d. & $18 \cdot 9$ & $\mathbf{I} \cdot \mathbf{I}$ & 33 & 0.6 & $5 \cdot 8$ & 0.8 & $32 \cdot 7$ \\
\hline Aspartate & $4 \cdot 3$ & $7 \cdot 5$ & 0.3 & $1 \cdot 8$ & $2 \cdot 9$ & $2 \cdot I$ & $6 \cdot 8$ & $8 \cdot 0$ \\
\hline Lysine & 0.5 & n.d. & $2 \cdot 0$ & $I \cdot 3$ & $\mathrm{I} \cdot 8$ & $I \cdot 2$ & $I \cdot 8$ & $2 \cdot 2$ \\
\hline Isoleucine & 0.2 & n.d. & 0.8 & 0.7 & 0.6 & 0.7 & 0.9 & $\mathrm{I} \cdot 5$ \\
\hline Serine & 0.5 & $I \cdot 4$ & 0.6 & $I \cdot 6$ & n.d. & 0.5 & 0.9 & 1.0 \\
\hline Glycine & 0.5 & $2 \cdot 0$ & $3 \cdot 4$ & $I \cdot 9$ & 0.8 & $2 \cdot I$ & $1 \cdot 8$ & $\mathrm{I} \cdot 8$ \\
\hline Alanine & $I \cdot O$ & $2 \cdot 0$ & $3 \cdot I$ & $4^{\cdot I}$ & $6 \cdot 0$ & $8 \cdot 1$ & $5 \cdot 5$ & $6 \cdot 8$ \\
\hline Valine & 0.5 & 0.7 & $4 \cdot 2$ & $4 \cdot 2$ & $7 \cdot 5$ & $4 \cdot 8$ & $2 \cdot 2$ & $4 \cdot I$ \\
\hline Leucine & 0.2 & n.d. & 0.9 & $I \cdot 2$ & $2 \cdot 9$ & $2 \cdot I$ & $2 \cdot 1$ & $2 \cdot 6$ \\
\hline $\begin{array}{l}\text { Total free } \\
\text { amino acid } \\
\text { pool (mM) }\end{array}$ & 139.4 & $187 \cdot 0$ & $122 \cdot 0$ & $167 \cdot 5$ & 135.4 & $187 \cdot 2$ & $I 6 I \cdot 5$ & $241 \cdot 4$ \\
\hline
\end{tabular}


'additional' potassium served an osmoregulatory function. However, no corresponding increase in the cellular contents of inorganic anions was found. Our results (Table 4; Fig. I $a$ ) suggest that glutamic acid may, in part, fulfil this requirement. In this connexion, it may be significant that Bacillus subtilis var. niger, which appeared always to contain much $\mathrm{K}^{+}$(Tempest, Dicks \& Ellwood, I968; Tempest, 1969) was always found to contain much free glutamic acid (Tables $I, 5$ ).

With cultures of Bacillus megaterium and B. polymyxa we have observed (Tempest, I969) that the cell-bound $\mathrm{K}^{+}$content was considerably lowered when growth was limited by the availability of $\mathrm{K}^{+}$; unlike $B$. subtilis var. niger (but like the Gramnegative bacteria), when $\mathrm{NaCl}$ was added to these $\mathrm{K}^{+}$-limited cultures the cellular $\mathrm{K}^{+}$ content increased markedly. Examination of the pools of $\mathrm{K}^{+}$-limited $B$. megaterium and $B$. polymyxa grown in the presence and absence of $\mathrm{NaCl}(2 \%, \mathrm{w} / \mathrm{v}$, final concentration) and, for comparison, $\mathrm{Mg}^{2+}$-limited organisms, revealed (Table 6) that changes in bacterial $\mathrm{K}^{+}$content were accompanied either by changes in bacterial free glutamate content or by changes in the intracellular levels of free lysine and DAP (two basic amino acids). However, the changes in cellular $\mathrm{K}^{+}$content were invariably much greater than the corresponding molar changes in free glutamate, lysine and DAP. Nevertheless, it is quite clear (Tables 4,6 ) that environmental conditions that prescribe an increased intracellular $\mathrm{K}^{+}$content also effected changes in the content and composition of bacterial free amino acid pools such that the net anion concentration was increased.

Table 6. The influence of medium $\mathrm{NaCl}$ content on the free amino acid pool content and composition in $\mathrm{K}^{+-}$-limited Bacillus megaterium and Bacillus polymyxa growing in simple salts media, in chemostats $\left(D=0.3 h^{-1}, 35^{\circ}, p H 6 \cdot 8\right)$

The conditions of growth and processing of samples were as described in Table I. Amino acid concentrations are expressed as $\mathrm{mm}$, assuming a cell water content of four times the dry weight of organisms.

\begin{tabular}{|c|c|c|c|c|c|c|}
\hline 然 & \multirow[b]{2}{*}{$\begin{array}{l}\mathrm{Mg}^{2+} \\
\text { limited }\end{array}$} & \multicolumn{2}{|c|}{$\mathrm{K}^{+}$-limited } & \multirow[b]{2}{*}{$\begin{array}{l}\mathrm{Mg}^{2+}- \\
\text { limited }\end{array}$} & \multicolumn{2}{|c|}{$\mathbf{K}^{+}$-limited } \\
\hline Amino acid & & $\begin{array}{l}\circ \% \\
\mathrm{NaCl}\end{array}$ & $\begin{array}{c}2 \% \\
\mathrm{NaCl}\end{array}$ & & $\begin{array}{l}0 \% \\
\mathrm{NaCl}\end{array}$ & $\begin{array}{c}2 \% \\
\mathrm{NaCl}\end{array}$ \\
\hline Glutamate & $56 \cdot 9$ & $30 \cdot 6$ & $87 \cdot 0$ & $82 \cdot 3$ & $44 \cdot 7$ & $4 I \cdot 7$ \\
\hline Glutamine/threonine & 0.4 & 0.4 & 0.8 & 20.9 & $13 \cdot 5$ & $38 \cdot 5$ \\
\hline Proline & 0.6 & 0.6 & $1 \cdot 0$ & n.d. & 0.8 & 0.5 \\
\hline Aspartate & 0.4 & 0.8 & $2 \cdot 2$ & $3 \cdot 1$ & $2 \cdot 7$ & 4.0 \\
\hline Lysine & 0.6 & $9 \cdot 4$ & $5 \cdot 3$ & $16 \cdot 5$ & $67 \cdot 7$ & $2 \cdot 1$ \\
\hline Isoleucine & 0.5 & $1 \cdot 3$ & $1 \cdot 8$ & $3 \cdot 3$ & 0.9 & n.d. \\
\hline Serine & 0.3 & $0 \cdot 3$ & $I \cdot 4$ & 0.5 & n.d. & 0.5 \\
\hline Glycine & $I \cdot 2$ & 0.8 & $1 \cdot 2$ & $7 \cdot I$ & 3.5 & $1 \cdot 4$ \\
\hline Alanine & $24 \cdot 8$ & $36 \cdot 0$ & $15 \cdot 8$ & $19 \cdot 8$ & $9 \cdot 6$ & $7 \cdot 5$ \\
\hline Valine & $3 \cdot 0$ & $3 \cdot 0$ & $6 \cdot 8$ & $2 \cdot 8$ & $2 \cdot 9$ & $1 \cdot 2$ \\
\hline Leucine & $I \cdot 2$ & 0.5 & 0.7 & n.d. & n.d. & n.d. \\
\hline DAP & n.d. & $16 \cdot 4$ & $7 \cdot 3$ & $\mathrm{I} \cdot 8$ & $3 \cdot 2$ & n.d. \\
\hline $\begin{array}{l}\text { Total free amino acid } \\
\text { pool (mM) }\end{array}$ & 89.9 & $100 \cdot 1$ & $131 \cdot 3$ & $158 \cdot I$ & 149.5 & $97 \cdot 9$ \\
\hline
\end{tabular}

Influence of environment on the content and composition of the amino acid pool of Saccharomyces cerevisiae

Data obtained for amino acid pools of Saccharomyces cerevisiae are shown in Table 7. $\mathrm{NH}_{3}$-limited yeast cells contained an amino acid pool of total size similar to that of the Gram-positive bacteria. Many differences, however, were apparent be- 
tween the composition of this yeast pool and that of any of the bacteria studied. Unlike its bacterial counterparts the yeast pool contained appreciable amounts of lysine, arginine and histidine while glutamic acid, although remaining the dominant constituent, accounted for a lesser proportion of the total pool. Yeast cells grown in glucose-limiting cultures contained a larger pool than those grown in $\mathrm{NH}_{3}$-limiting conditions. While all the pool constituents with the exception of aspartic acid and leucine were higher in these glucose-limited cultures, the largest increases were found in the concentrations of glutamic acid, alanine, valine, arginine and histidine.

Increasing the growth rate from 0.1 to $0.25 \mathrm{~h}^{-1}$ (near to the maximum growth rate in this medium) resulted in an increased pool size in glucose-limited cells (Table 7 ). In this case the concentrations of all the amino acids increased, with the exception of histidine, the largest increases being found in lysine, serine, glycine and arginine.

Cultures of Saccharomyces cerevisiae grew at a dilution rate of $0.1 \mathbf{h}^{-1}$ in glucoselimited media containing up to $4 \%(\mathrm{w} / \mathrm{v}) \mathrm{NaCl}$. Such concentrations of $\mathrm{NaCl}$, however, did not affect the size of the amino acid pool (assayed with ninhydrin) nor its composition.

Table 7. The pool free amino acid contents of Saccharomyces cerevisiae grown in chemostat cultures $\left(25^{\circ}, \mathrm{pH} 4.5\right)$ in simple salts media

Organisms were grown, and samples prepared, as described in Methods. The concentration of each amino acid in extracts was assessed by measurement of peak areas on the traces from the amino acid analyser. The concentrations were related to the intracellular free amino acid concentrations by assuming a cell water content of four times the yeast dry weight.

\begin{tabular}{|c|c|c|c|}
\hline \multirow[b]{3}{*}{ Amino acid } & \multicolumn{3}{|c|}{ Intracellular free amino acid concentration (mM) } \\
\hline & \multirow{2}{*}{$\begin{array}{l}\mathrm{NH}_{3} \text {-limited } \\
D=0 . \mathrm{h}^{-1}\end{array}$} & \multicolumn{2}{|c|}{ Glucose-limited } \\
\hline & & $D=0 . \mathrm{I} \mathrm{h} .^{-1}$ & $D=0.25 \mathrm{~h}^{-1}$ \\
\hline Glutamate & $35 \cdot 6$ & $135 \cdot 4$ & $146 \cdot 8$ \\
\hline Threonine & 13.5 & $25 \cdot 8$ & $30 \cdot 6$ \\
\hline Proline & n.d. & n.d. & n.d. \\
\hline Aspartate & $10 \cdot 7$ & II $\cdot 2$ & $16 \cdot 3$ \\
\hline Lysine & II $\cdot 5$ & $25 \cdot 8$ & $76 \cdot 5$ \\
\hline Isoleucine & $5 \cdot 7$ & n.d. & $10 \cdot 0$ \\
\hline Serine & $15 \cdot 1$ & $13 \cdot 2$ & $34 \cdot 8$ \\
\hline Glycine & $8 \cdot 6$ & $12 \cdot 0$ & $40 \cdot I$ \\
\hline Alanine & $17 \cdot 9$ & 54.9 & 63.9 \\
\hline Valine & $9 \cdot 3$ & 24.0 & $26 \cdot 4$ \\
\hline Leucine & $7 \cdot 2$ & I·9 & $7 \cdot 9$ \\
\hline Arginine & $6 \cdot 4$ & $45 \cdot 5$ & $67 \cdot 5$ \\
\hline Histidine & $2 \cdot 8$ & II $\cdot 2$ & $8 \cdot 4$ \\
\hline \multirow{2}{*}{$\begin{array}{l}\text { Total free } \\
\text { amino acid } \\
\text { pool (mM) }\end{array}$} & $144 \cdot 3$ & 380.9 & $529 \cdot 2$ \\
\hline & \multicolumn{3}{|c|}{ n.d. = Not detectable. } \\
\hline
\end{tabular}

Free amino acids lie directly on the pathway of synthesis of proteins from carbohydrates and $\mathrm{NH}_{3}$; therefore it is reasonable to suppose that significant amounts of these intermediary substances would always be present within the growing cell. But the distribution of amino acids in the pools which we examined bore no relationship to their contribution to microbial proteins. In particular, the bacterial pools invariably 
lacked detectable amounts of tryptophan, tyrosine, phenylalanine and cysteine while only the yeast pools contained histidine and arginine. Of the amino acids regularly present in bacterial pools, leucine, isoleucine, serine, glycine, aspartate, valine, lysine and proline were frequently present in low concentrations. In fact, only glutamate and alanine appeared always to be present in substantial amounts in bacterial pools, and glutamate nearly always predominated (Tables $I$ to 6). Thus, since the content and composition of bacterial amino acid pools could not be related, directly or indirectly, to the protein content and composition of the cells, they must therefore have some other significance.

Clearly (Table I) there are large differences between the free amino acid pool contents of Gram-positive and Gram-negative bacteria, even when these various organisms are grown at identical rates in identical media. However, in every case shown in Table I glutamate was the predominant amino acid and accounted for between 52 and $89 \%$ of the total pool free amino acid contents of these $\mathrm{NH}_{3}$-limited organisms. Furthermore, when large changes in pool amino acid contents were provoked (by varying the growth rate or the medium $\mathrm{NaCl}$ content) almost invariably there were correspondingly large changes in pool glutamate levels. In Gram-negative organisms particularly, the pool glutamate levels were most sensitive to changes in environment. Thus, in attempting to rationalize the effects of environment on pool content and composition, it is necessary to account principally for $(a)$ the large differences between the pool glutamate contents of Gram-positive and Gram-negative bacteria, and $(b)$ the gross effects of medium osmolarity on the intracellular levels of free glutamate in Gram-negative bacteria.

In bacteria, glutamate is generally synthesized from 2-oxoglutarate and $\mathrm{NH}_{3}$ by glutamate dehydrogenase (EC I.4.I.4). Therefore, changes in the free glutamate content of bacteria, growing at a fixed rate, must be mediated by changes in either the cellular content or activity of this enzyme. In fact, rapid changes in bacterial pool glutamate levels (such as occurred when $\mathrm{NaCl}$ was added to the growth environment) could only have resulted from a change in enzyme activity. In this connexion, a detailed examination of glutamate dehydrogenase from Aerobacter aerogenes showed it to have a marked $\mathrm{pH}$ dependence (Fig. 3). Now, addition of $\mathrm{NaCl}$ to suspensions of $A$. aerogenes invariably caused a rapid efflux of $\mathrm{H}^{+}$from the organisms which could be measured as a decrease in extracellular $\mathrm{pH}$; thus, presumably, the intracellular $\mathrm{H}^{+}$ decreased correspondingly. This would effect a marked increase in glutamate dehydrogenase activity and an increase in the rate of glutamate synthesis. The synthesis of glutamate de novo (from glucose and $\mathrm{NH}_{3}$ ) would tend to restore the intracellular $\mathrm{H}^{+}$ concentration and thereby decrease the rate of glutamate synthesis to a new steady state value. Thus changes in glutamate dehydrogenase activity would provide a compact feedback control system for maintaining the intracellular $\mathrm{H}^{+}$concentration constant, and it probably is this maintenance of intracellular $\mathrm{H}^{+}$concentration that dictates the levels of glutamate in Gram-negative bacteria.

On the other hand, the marked differences between the glutamate contents of Gramnegative and Gram-positive bacteria cannot be accounted for in terms of their glutamate dehydrogenase contents or activities (see Meers, Tempest \& Brown, 1970). In some respects, Gram-positive bacteria resemble Gram-negative bacteria that have been grown in the presence of much $\mathrm{NaCl}$ (for example, in having much cell-bound potassium and free glutamate) but in other respects the organisms are quite different. 
Thus addition of $\mathrm{NaCl}$ to growing cultures of Bacillus subtilis var. niger caused no plasmolysis and no immediate increase in bacterial glutamate and potassium contents (Fig. $\mathrm{I} b$ ). Ultimately the pool glutamate (and potassium) contents did increase (Table 5), but the slowness of this change suggested that it had resulted more from some progressive change in cell structure (for example, in their wall content and composition; see Meers \& Tempest, 1969) rather than in the functioning of the organisms.

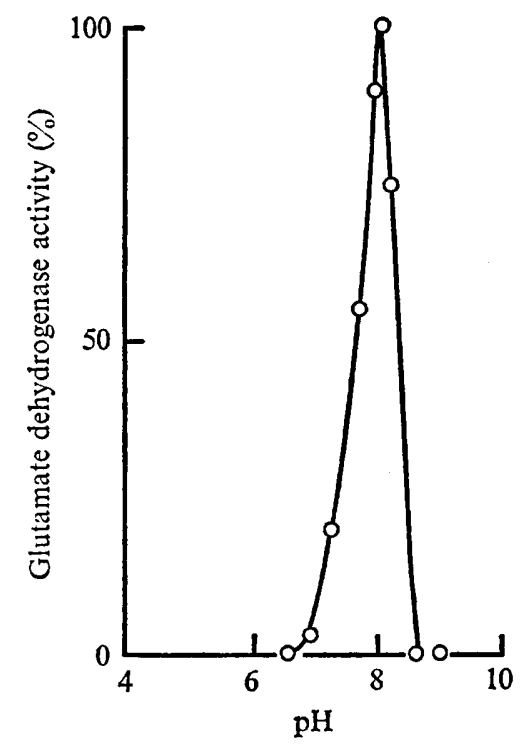

Fig. 3. Influence of $\mathrm{pH}$ on the activity of glutamate dehydrogenase extracted from glucoselimited Aerobacter aerogenes grown in a chemostat at a dilution rate of $0.3 \mathrm{~h}^{-1}\left(35^{\circ}, \mathrm{pH} 6.8\right)$.

It is clear that, in growing bacteria, some correlation exists between their contents of potassium and free glutamate (see Tables I to 6 and the papers of Tempest \& Dicks, 1967; Tempest \& Meers, I968). But whether changes in bacterial potassium content effect changes in pool glutamate level, or vice versa, is not obvious. Potassium contributes substantially to the net cation content of bacteria, and free glutamate presumably contributes (although not equivalently) to the net anion content. Clearly, in $\mathrm{K}^{+}$-limited Bacillus megaterium and B. polymyxa cultures the pool basic amino acids (lysine and DAP) spared to some extent the bacterial requirement for $\mathrm{K}^{+}$. Significantly, however, these organisms did not respond to changes in medium $\mathrm{NaCl}$ content by increasing their intracellular concentrations of basic amino acids; instead, the rates of synthesis of these basic amino acids were decreased whilst glutamate and $\mathrm{K}^{+}$ accumulated (Table 6).

The amino acid pools of Saccharomyces cerevisiae, unlike those of any of the bacteria studied, showed large changes with variations in the nature of the growth-limiting substrate. It appears likely that the supply of $\mathrm{NH}_{3}$ limits the size of the yeast pool and in particular the concentrations of those amino acids containing more than one nitrogen atom per molecule (for example, arginine and lysine). In all cases studied, increasing the growth rate of a culture (and hence the rate of protein synthesis) resulted in a swelling of the amino acid pool thus reflecting the precursor nature of such pools 
The limited distribution of the amino acids present in detectable amounts in the pools of micro-organisms, growing in a simple salts environment, is surprising. However, examination of the pathways by which the various amino acids regularly present in these pools arise shows that in the majority of cases they lie close to intermediary metabolites formed in the oxidation of glucose; that is, their synthesis requires only a few additional enzyme-catalysed reactions. It is clear (Table 5; Fig. 2) that with cultures of Bacillus subtilis var. niger increases in pool glutamate content, following addition of 2 to $6 \%(\mathrm{w} / \mathrm{v}) \mathrm{NaCl}$ to the culture, were accompanied by substantial increases in the metabolically associated amino acids, glutamine and, particularly, proline. But no proportionality is apparent between the concentrations of these three amino acids in bacterial pools, nor between other groups of amino acids that arise from a common precursor.

We are most grateful to $\mathrm{Mr}$ J. H. R. Slade for carrying out the amino acid analyses, and to $\mathrm{Mr}$ T. H. Dunham for skilled technical assistance.

\section{REFERENCES}

BrtTten, R. J. \& MCCluRe, F. T. (1962). The amino acid pool in Escherichia coli. Bacteriologica Reviews 26, 292-304.

BRown, C. M. \& Hough, J. S. (1965). Elongation of yeast cells in continuous culture. Nature, London 206, 676-678.

Brown, C. M. \& Rose, A. H. (1969a). Effects of temperature on composition and cell volume of Candida utilis. Journal of Bacteriology 97, 26r-272.

Brown, C. M. \& Rose, A. H. (1969b). Fatty acid composition of Candida utilis as affected by growth temperature and dissolved oxygen tension. Journal of Bacteriology 99, 371-378.

Dawson, P.S. S. (1965). The intracellular amino acid pool of Candida utilis during growth in batch and continuous flow culture. Biochimica et biophysica acta III, 5I-66.

EpsteIN, W. \& Schultz, S. G. (1965). Cation transport in Escherichia coli. V. Regulation of cation content. Journal of General Physiology 49, 221-234.

HERBERT, D. (1961). The chemical composition of micro-organisms as a function of their environment. Symposia of the Society for General Microbiology Ir, 391-416.

Herbert, D., PhipPs, P. J. \& Tempest, D. W. (1965). The chemostat:design and instrumentation. Laboratory Practice 14, I I50-I I6I.

Holden, J. T. (1962). The composition of microbial amino acid pools. In Amino Acid Pools, p. 73. Edited by J. T. Holden. Amsterdam: Elsevier Publ. Co.

MANDELSTAM, J. (1958). The free amino acids in growing and non-growing populations of Escherichia coli. Biochemical Journal 69, 103-I 10.

MeERs, J. L. \& TeMPeST, D. W. (1969). The influence of environment on the synthesis of magnesiumbinding sites in Bacillus subtilis var. niger cell walls. Journal of General Microbiology 55, $\mathrm{x}$.

MeErs, J. L., Tempest, D. W. \& Brown, C. M. (1970). 'Glutamine(amide): 2-oxoglutarate aminotransferase oxido-reductase (NADP)', an enzyme involved in the synthesis of glutamate by some bacteria. Journal of General Microbiology 64, 187-194.

NeIHARDT, F. C. (1963). Effect of environment on the composition of bacterial cells. Annual Review of Microbiology 17, 6I-86.

TAYLOR, E. S. (1947). The assimilation of amino acids by bacteria. III. Concentration of free amino acids in the internal environment of various bacteria and yeasts. Journal of General Microbiology I, 86-90.

TEMPEST, D. W. (1969). Quantitative relationships between inorganic cations and anionic polymers in growing bacteria. Symposia of the Society for General Microbiology I9, 87-I I I.

TEMPEST, D. W. (1970). The place of continuous culture in microbiological research. Advances in Microbial Physiology 4, 223-250. 
TEMPEST, D. W.\& Dicks, J. W. (1967). Interrelationships between potassium, magnesium, phosphorus and ribonucleic acid in the growth of Aerobacter aerogenes in a chemostat. In Microbial Physiology and Continuous Culture, p. I40. London: H.M.S.O.

Tempest, D. W., Dicks, J. W. \& Ellwood, D. C. (1968). Influence of growth condition on the concentration of potassium, and its possible relationship to ribonucleic acid, teichoic acid and teichuronic acid in Bacillus subtilis var. niger. Biochemical Journal 106, 237-243.

Tempest, D. W., Hunter, J. R. \& SyKes, J. (1965). Magnesium-limited growth of Aerobacter aerogenes in a chemostat. Journal of General Microbiology 39, 355-366.

Tempest, D. W. \& MeERs, J. L. (1968). The influence of $\mathrm{NaCl}$ concentration of the medium on the potassium content of Aerobacter aerogenes and on the interrelationships between potassium, magnesium and ribonucleic acid in the growing bacteria. Journal of General Microbiology 54, 319325 .

Tempest, D. W., Meers, J. L. \& Brown, C. M. (1970). Influence of environment on the free amino acid 'pool' content of bacteria. Journal of General Microbiology 6o, ix. 